\title{
СПИКЕРЫ РЕГИОНАЛЬНЫХ ЗАКОНОДАТЕЛЬНЫХ СОБРАНИЙ: КАРЬЕРНЫЕ ПУТИ И КАНАЛЫ РЕКРУТИРОВАНИЯ ${ }^{1}$
}

\author{
Д.Б. Тев
}

(denis_tev@mail.ru)
Социологический институт РАН - филиал ФНИСЦ РАН,
Санкт-Петербург, Россия

Цитирование: Тев Д.Б. Спикеры региональных законодательных собраний: карьерные пути и каналы рекрутирования // Власть и элиты. 2021. Т. 8, № 1. C. 28-65.

DOI: https://doi.org/10.31119/pe.2021.8.1.2

Аннотация. Рассматриваются каналь рекрутирования спикеров легислатур субъектов РФ и особенности их карьеры как до избрания, так и после ухода с должности. Эмпирической основой исследования послужила биограбическая база данных председателей региональных законодательных собраний всех созывов после окончания полномочий последних советов народных депутатов и до февраля 2019 г. Установлено, что спикеры сильно укоренены в органах политико-административной власти советского общества, хотя доля номенклатурных, прежде всего партийных, кадров имеет выраженную тендениию к уменьшению. Основным каналом рекрутирования спикеров и местом их работы после отставки являются органы представительной власти, прежде всего региональные легислатуры. Избрание спикеров из относительно опытных депутатов-профессионалов может свидетельствовать об известной автономизаиии и институиионализаиии законодательных собраний. Впрочем, эта тенденция довольно

${ }^{1}$ Статья представляет собой переработанную и расширенную версию статьи, опубликованной ранее в «Социологическом журнале» [Тев 2021]. 
ограниченна: тесная связь с влиятельными внешними силами (административными, экономическими), контролируюшими легислатуру, может выступать "выттягивающим» фактором законодательной карьерь, освобождая спикеров от необходимости предварительного политического «ученичества» в парламенте. Важный канал рекрутирования спикеров административные органы, прежде всего региональные и местные, что во многом отражает зависимость формирования и функиионирования легислатур от губернаторов, стремящихся поставить во главе них персон из своей клиентель. Существенно реже спикеры работают в административных структурах после отставки, прежде всего на посту губернатора, причем практика их рекрутирования на эту должность была наиболее распространена в 1990-е годы. Значимым источником рекрутирования спикеров служит бизнес, однако непосредственных выходиев из коммерческих организаиий (чаще всего из крупных по региональным меркам) относительно немного, что может отражать как важность предварительной политической профессионализации для достижения этого поста, так и контроль над законодательными собраниями со стороны губернаторов, которым частные бизнесмены могут казаться слишком независимыми бигурами для роли спикера. Реже спикеры заняты в бизнесе после ухода с должности, при этом довольно распространены их возвраты в те компании, в которых, они работали до избрания.

Ключевые слова: спикерь, региональные легислатуры, каналь рекрутирования, карьера, номенклатурный опыт, представительные органы, административные органы, бизнес.

\section{ВВЕДЕНИЕ}

Важность исследования председателей (спикеров) региональных законодательных собраний (далее 3С) как сегмента властной элиты во многом связана со значимостью тех органов, которые они возглавляют. Роль легислатур в системе власти субъектов РФ варьировалась в историческом плане. В 1990-е годы имело место относительное разнообразие региональных политических режимов и в связи с этим типов легислатур [Гельман 1998; Кузьмин, Мелвин, Нечаев 2002]. Хотя в этот период во многих регионах парламенты были подчинены исполнительной власти, в некоторых они играли значительную самостоятельную роль, иногда возникали легислатуры, оппозиционные губернаторам. Однако в конце 1990-х - начале 2000-х годов легислатуры ослабли, как правило оказавшись под контролем глав регионов, что характерно 
и для настоящего времени ${ }^{1}$ [Туровский 2011; Шириков 2010; Golosov $2017]^{2}$. Этот контроль осуществляется «главным образом посредством патронажной машинной политики, которая... включает в себя выстраивание устойчивых связей между действующим губернатором и его клиентами в региональных законодательных элитах» [Golosov 2017: 557-558]. Впрочем, при всей своей зависимости от региональных администраций 3С обладают существенными полномочиями (от принятия бюджета и программ социально-экономического развития субъектов РФ до утверждения назначений чиновников) и обычно остаются довольно значимыми институтами, а не декоративными «витринами» с чисто символической ролью. Об этом косвенно говорит то, что они, как правило, включают крупных по региональным меркам бизнесменов и других высокопоставленных персон и в целом членство в них традиционно ассоциируется с элитным статусом [Golosov 2014: 5]. Вообще в литературе показано, что легислатуры в авторитарных условиях выполняют важные функции, способствуя повышению жизнеспособности автократий [Gandhi, Przeworski 2007; Jensen, Malesky, Weymouth 2014; Malesky, Schuler 2010; Reuter, Robertson 2015; Wright 2008]. Одна из них заключается в кооптации оппозиции и ослаблении социального протеста [Reuter, Robertson 2015; Туровский, Сухова 2021]. В тесной связи с этим они также функционируют как арены, на которых различные члены и сегменты властной (прежде всего региональной) элиты согласовывают свои интересы, ведут торг и переговоры, соревнуются за влияние и блага [Reuter, Robertson 2015: 238].

Легислатуры субъектов РФ, как и все законодательные органы, устроены иерархически, и их председатели (спикеры), как правило, являются наиболее политически влиятельными депутатами. Несмотря на типичную слабость 3С, обычно они занимают высокие позиции в рейтингах влияния политической элиты субъектов РФ [Петров 2007: 82]. Спикеры могут играть значительную роль в региональной политике, в частности в регулировании взаимоотношений и конфликтов, согласовании интересов членов и сегментов региональной элиты, в рас-

${ }^{1}$ Хотя и в 2010-е годы роль легислатур не оставалась неизменной: их политическое влияние усилилось в 2011-2012 гг. и ослабло в дальнейшем [Кынев 2020: 971].

${ }^{2}$ Об эволюции взаимоотношений региональной администрации и $3 \mathrm{C}$ в 2000-е годы на примере Санкт-Петербурга см.: [Даугавет 2012]. 
пределении между ними различных выгод и пр. Во многом это связано с тем, что они обладают рядом важных формальных полномочий. Обычно спикер созывает и ведет пленарные заседания 3С, представляет его в отношениях с другими органами власти и прочими организациями, подписывает постановления собрания, а также иные документы от его имени, распределяет обязанности между своими заместителями, назначает главу и руководит деятельностью аппарата собрания, является распорядителем по его лицевому счету и пр. Благодаря своим прерогативам спикер может обладать существенной институциональной властью: процедурной, ресурсной и пр. Так, ведя заседания легислатуры, он может пользоваться некоторой свободой в определении того, какие вопросы и когда должны вноситься и обсуждаться, кто из депутатов должен выступать и пр. Спикер имеет возможность интерпретировать процедурные правила и разрешать соответствующие споры и неопределенности. Все это, в свою очередь, позволяет ему оказывать влияние и на результаты законодательного процесса. Кроме того, контролируя аппарат легислатуры, обеспечивающий ее работу в кадровом, материально-техническом, финансовом и прочих отношениях, спикеры могут влиять на распределение между депутатами и их коалициями важных ресурсов. В силу этого у них появляется возможность вознаграждать и наказывать своих коллег, обеспечивая лояльность с их стороны. Тот факт, что спикеры представляют законодательные собрания в отношениях с другими органами власти, дает им привилегированный доступ к чиновникам, расширяя возможности воздействовать на политику. Кроме того, некоторые факторы могли в разное время способствовать повышению статуса и усилению влияния спикеров. Во-первых, во второй половине 1990-х - начале 2000-х годов они, наряду с губернаторами, по должности были членами Совета Федерации (далее СФ), что означало их принадлежность не только к региональной, но и к федеральной элите, усиливало иерархичность в их отношениях с другими депутатами и давало им прямые возможности влиять на общенациональную политику. Во-вторых, в 2005-2012 гг., когда выборы губернаторов были отменены, влиятельность и престижность должности спикера могли возрасти, благодаря тому что они оказались высшими региональными руководителями, получившими электоральную легитимность.

Важность институциональных каналов рекрутирования спикеров региональных 3С и их карьеры до вхождения в должность и после 
ухода с нее как предмета исследования связана с рядом обстоятельств. Вообще эти характеристики элитных персон могут служить показателем структуры социальной и политической власти, которая лежит в основе их рекрутирования. В частности, изучение источников рекрутирования и карьерных траекторий спикеров в постсоветский период дает возможность лучше понять такие особенности региональной системы власти в ее исторической эволюции, как характер взаимоотношений законодательных и исполнительных органов, бизнеса и государства и пр. Во-вторых, социально-профессиональное происхождение и карьера законодателей вообще (и спикеров в частности) могут в определенной степени влиять на их политические аттитюды и поведение (хотя автоматической связи здесь нет, но ряд исследования показывают такую зависимость [Carnes 2012; Carnes, Lupu 2015; Chaisty 2013; Witko, Friedman 2008]). Причем не только предшествующая карьера, но и карьера после ухода с должности могут быть связаны с поведением законодателей в период пребывания в ней, поскольку они способны приспосабливать свою политику к интересам потенциального, будущего работодателя [Samuels 2003: 134-156]. Следовательно, знание источников рекрутирования и карьеры спикеров ЗС дает возможность в определенной мере прогнозировать их политику.

Хотя социально-профессиональное происхождение, каналы рекрутирования и предшествующая карьера регионального депутатского корпуса России в целом довольно подробно изучались на материале, как отдельных субъектов РФ, так и групп регионов (см. обзор: [Быстрова и др. 2019]), данные характеристики руководства легислатур и, в частности, их спикеров редко становились объектом специального исследования. Важным исключением является статья Л.В. Богатыревой [Богатырева 2012], которая проанализировала, хотя и не очень подробно, каналы рекрутирования глав легислатур в регионах ЦФО в 1993-2011 гг. Также нужно отметить статью О.Дж. Рейтера и Р. Туровского [Reuter, Turovsky 2014], в которой, в частности, показано, что представители различных профессиональных категорий с разной вероятностью достигают руководящих постов в легислатурах (включая должность спикера): с большей - выходцы из региональной администрации и профессиональные депутаты, с меньшей - бюджетники и бизнесмены. Эти работы серьезно улучшили наше понимание рассматриваемой темы. Однако отсутствие тщательного исследования каналов рекрутирования спикеров, которое бы охватило все субъекты РФ за весь 
постсоветский период, препятствует выявлению долговременных тенденций в их карьере в меняющемся общественно-политическом контексте и пониманию того, насколько широко те или иные карьерные паттерны распространены в региональном разрезе. Кроме того, отсутствие комплексного анализа профессионального пути спикеров не только до вхождения в должность, но и после отставки затрудняет выяснение роли этой должности в карьере властных персон (является ли она ее вершиной или трамплином к более высоким постам и пр.).

\section{ЭМПИРИЧЕСКАЯ ОСНОВА И МЕТОД ИССЛЕДОВАНИЯ}

Объектом исследования стали председатели (только «полноправные», исключая исполняющих обязанности) региональных 3С всех созывов после прекращения полномочий последних советов народных депутатов (чаще всего в 1993 или 1995 гг.) и до начала февраля 2019 г. Применительно к некоторым регионам (Чечне, Крыму, Севастополю) в силу специфики их истории временные рамки исследования оказались значительно более узкими. Нужно также отметить, что в целом ряде регионов, например таких как Свердловская область или Республика Тыва, легислатуры некоторое время были двухпалатными, и в этом случае в анализ включались спикеры обеих палат.

На каждого спикера была заполнена биографическая анкета, содержащая информацию о дате и месте рождения, типе и месте получения высшего образования, карьерном пути как до вхождения в должность, так и после ухода с нее (данные собирались в январе-феврале 2019 г.). Источниками информации служили сайты органов государственной власти, коммерческих организаций, бюджетных учреждений и иных структур, отчеты компаний, материалы СМИ, биографические интернет-порталы (viperson.ru, lobbying.ru).

Таблица 1 показывает параметры исследуемой совокупности, которая исчерпывает генеральную совокупность спикеров.

Таблиияа 1

Количественные характеристики исследуемой совокупности спикеров

\begin{tabular}{|l|c|}
\hline \multicolumn{1}{|c|}{ Показатель } & 3начение \\
\hline Число персон, занимавших пост спикера, и анкет в базе данных & 446 \\
\hline Число вхождений в должность спикера & 461 \\
\hline $\begin{array}{l}\text { Число выбытий с должности спикера } \\
\text { (исключая случаи смерти в должности) }\end{array}$ & 361 \\
\hline
\end{tabular}


Поскольку некоторые из них дважды с перерывом возглавляли легислатуру, число вхождений в должность и предшествующих карьерных траекторий оказалось больше числа персон и анкет в базе данных. Поскольку часть спикеров находилась в должности на момент сбора данных, число уходов с поста спикера и возможных посткарьерных траекторий меньше числа вхождений.

\section{ВЫХОДЦЫ И НОМЕНКЛАТУРЫ СРЕДИ СПИКЕРОВ}

Одной из важных характеристик постсоветских элит, привлекающей внимание исследователей, является степень их укорененности в структурах политико-административной власти советского общества, в номенклатуре. Вопрос об уровне номенклатуризации властных групп активно обсуждался в научной литературе в связи с более общей проблематикой их воспроизводства/циркуляции в процессе радикальной общественной трансформации [Böröcz, Róna-Tas 1995; Hanley, Yershova, Anderson 1995; Szelényi, Szelényi 1995]. Кроме прочего, его важность связана с тем, что, как показывают некоторые исследования, наличие опыта работы в партийных, советских и комсомольских органах (номенклатурного опыта) - один из факторов, дифференцирующих политические ценности и аттитюды членов элиты [Региональные элиты... 2001; Сафронов 2010]. Исследования 1990-х - начала 2000-х годов выявили, что в постсоветской России уровень номенклатуризации политико-административной элиты, особенно региональной, был высоким, впрочем, со временем старение номенклатурных кадров способствовало сокращению их присутствия во властных группах [Крыштановская 1995; Böröcz, Róna-Tas 1995; Hanley, Yershova, Anderson 1995; Szelényi, Szelényi 1995; Быстрова 2012: 92; Тев 2017; Быстрова и др. 2020].

Нынешнее исследование выявило, что номенклатура - весьма важный источник рекрутирования спикеров. Без малого половина (49 \%) спикеров имеет опыт работы в органах КПСС (42\%) и/или ВЛКСМ (23 \%). Кроме того, многие председатели легислатур работали в советских исполнительных и представительных органах власти, в основном местных и региональных, до 1990 г. Некоторые будущие председатели легислатур занимали очень высокие должности в региональной номенклатуре. Среди них девять первых и столько же других секретарей обкомов КПСС, а также ряд председателей обл- 
исполкомов и их заместителей. Впрочем, гораздо чаще они возглавляли партийные комитеты районного или городского уровня. Следует отметить, что практика избрания спикерами деятелей с номенклатурным прошлым встречается практически во всех регионах, в частности только в семи субъектах РФ (включая Санкт-Петербург и Чечню) среди спикеров никогда не было лиц, работавших в органах КПСС. В общем степень преемственности корпуса спикеров с политико-административной номенклатурой местного и регионального уровня довольно высока.

Карьерные пути представителей номенклатуры к должности спикера постсоветской легислатуры различны. Так, некоторые выходцы из нее после 1990 г., когда власть переходила от партийных органов к советским, заняли руководящие позиции в первых конкурентно избранных советах народных депутатов, в целом ряде случаев став их председателями. После прекращения полномочий советов они, пользуясь преимуществами инкумбентов, были избраны в законодательные собрания первого созыва и возглавили эти органы, состав которых нередко имел существенную преемственность с последним советом. Так, из девяти обнаруженных среди спикеров первых секретарей обкомов КПСС шестеро возглавили первый демократически сформированный совет народных депутатов, а позднее и законодательное собрание первого созыва и, что интересно, четверо из них затем стали губернаторами. Однако большинство спикеров с номенклатурным прошлым в постсоветский период сначала некоторое время занимали ключевые посты в администрациях местного и/или регионального уровня и/или, но существенно реже, в коммерческих организациях, которые, как будет показано ниже, выступали важным трамплином к вхождению в легислатуру и посту спикера.

Исследователи отмечали, что способность деятелей номенклатуры поддерживать свой элитный статус в условиях глубоких и быстрых институциональных изменений во многом коренится в тех персональных сетях, которые их связывают с советского времени [Hanley, Yershova, Anderson 1995: 662]. Ввиду этого нужно отметить, что, как показывают некоторые биографии, знакомства и связи, приобретенные в годы номенклатурной работы, действительно могли играть роль важного «вытягивающего фактора» в карьере спикеров, причем спустя даже довольно длительное время после распада СССР. В качестве примера можно привести председателя Липецкого областного совета депу- 
татов (с 2005 г.) П.И. Путилина, который в прежние времена заведовал отделом в Добринском райкоме КПСС, первым секретарем которого был будущий губернатор региона.

Следует, впрочем, отметить, что, как показывают биографии, превращение бывших деятелей номенклатуры в спикеров легислатур и в целом воспроизводство ими элитного статуса в постсоветский период не всегда происходило гладко. В ряде случаев мы видим периоды (хотя и часто короткие) глубоких карьерных спадов, резко нисходящей социально-профессиональной мобильности, особенно в 1991 г. (после роспуска КПСС) и в 1993 г. (после ликвидации Советов), что характерно прежде всего для спикеров, связанных с КПРФ. Например, глава Палаты Республики Законодательного собрания Карелии В.В. Шильников, бывший до 1991 г. секретарем ОК КПСС, в 1991-1994 гг. работал доцентом университета, затем был избран в региональную легислатуру, став спикером в 2000 г. Председатель Костромской областной думы В.П. Ижицкий до 1991 г. был первым секретарем Костромского ГК КПСС, а затем преподавателем и заведующим кафедрой педагогического института, в 1994 г. стал депутатом областного парламента, а в 2000 г. возглавил его.

Хотя выходцы и номенклатуры исторически преобладали среди спикеров, существует, как показывает таблица 2, неуклонная тенденция к сокращению их доли.

Таблица 2

\section{Опыт работы спикеров в органах КПСС и ВЛКСМ по времени вхождения в должность, в \%}

\begin{tabular}{|c|c|c|}
\hline Время вхождения в должность & КПСС & ВЛКСМ \\
\hline $1990-\mathrm{e}(\mathrm{n}=160)$ & 62,5 & 26 \\
\hline $2000-\mathrm{e}(\mathrm{n}=166)$ & 41 & 26 \\
\hline $2010-\mathrm{e}(\mathrm{n}=135)$ & 19 & 18 \\
\hline
\end{tabular}

Кроме уже отмеченного старения номенклатурных кадров (естественной причины их ухода, которая должна сильнее проявиться по отношению к деятелям КПСС, чем более молодым комсомольским работникам), снижению уровня номенклатуризации в некоторой мере могло способствовать и ослабление в 2000-е годы позиций КПРФ в региональных легислатурах (среди спикеров, связанных с ней, опыт работы в органах КПСС был особенно распространен). 


\section{ОПЫТ РАБОТЫ В ПРЕДСТАВИТЕЛЬНЫХ ОРГАНАХ ${ }^{1}$ И ПОЛИТИЧЕСКАЯ ПРОФЕССИОНАЛИЗАЦИЯ}

\section{Предшествующий законодательный опыт спикеров}

Законодательный опыт - самый распространенный тип профессионального опыта, предшествующего избранию спикером. Как показывает таблица 3, подавляющее большинство председателей имеет его на том или ином уровне власти после первых конкурентных выборов 1990 г. и до вхождения в должность.

Более 30 \% заседали в представительных органах половину или большую часть своей карьеры после 1990 г. и до избрания председателем.

1 Членство в органах представительной власти не единственный тип постсоветского политического опыта, играющий значимую роль в карьере спикеров. В настоящее время важно также членство и особенно руководящая работа в политической партии. Однако в исторической перспективе значимость партийной принадлежности сильно варьировалась. В 1990-е - начале 2000-х годов партии обычно играли слабую роль на выборах в региональные легислатуры. Будущие и действующие спикеры, как правило, избирались в парламент по одномандатным округам в качестве беспартийных самовыдвиженцев. Тем не менее некоторые из них все же были связаны с партиями и занимали руководящие посты в них, прежде всего в КПРФ, но также и в НДР и др. В 2000-е годы реформы избирательного законодательства способствовали изменению роли партий в формировании и функционировании региональных легислатур. В этой период происходит резкое падение доли одномандатников и самовыдвиженцев среди председателей и рост доли избранных в ЗС по партийному списку [Богатырева 2012: 182-187]. Ныне принадлежность к «партии власти», по сути, превратилась в обязательное условие избрания председателем. Во всех субъектах РФ действующие на февраль 2019 г. спикеры были избраны в нынешний созыв 3С от «Единой России», несколько чаще по спискам, чем по одномандатным округам. Более того, с 2010-х годов распространилась практика совмещения должности спикера с постом секретаря регионального отделения (РО) ЕР [Кынев 2020: 680]. Из 84 действующих спикеров 46 то или иное время (иногда очень краткое) совмещали эти позиции, чаще становясь партийными лидерами после, чем до избрания спикером. Возглавляя РО, спикер берет на себя персональную ответственность за результаты «партии власти» на выборах и в случае неудачи может потерять свою должность. Уход с поста спикера обычно влечет за собой утрату поста секретаря, но экс-председатели нередко продолжают входить в руководство РО и избираться от ЕР в органы представительной власти. 
Таблиия 3

Опыт членства спикеров в представительных органах перед избранием, в \% $(\mathrm{N}=461)$

\begin{tabular}{|c|c|c|}
\hline Уровень легислатуры & $\begin{array}{c}\text { Наличие } \\
\text { опыта }\end{array}$ & $\begin{array}{c}\text { Последняя известная } \\
\text { должность перед } \\
\text { избранием } \\
\end{array}$ \\
\hline $\begin{array}{l}\text { Федеральный (народные депутаты } \\
\text { РСФСР-РФ 1990-1993 гг., депутаты } \\
\text { ГД и депутаты/члены СФ) }\end{array}$ & 10 & 5 \\
\hline \multicolumn{3}{|l|}{ В m.ч. } \\
\hline Федеральное собрание & 6 & 4 \\
\hline \multicolumn{3}{|l|}{ B m.ч. } \\
\hline ГД & 2 & 1 \\
\hline CФ & 5 & 3 \\
\hline Региональный с 1990 г. & $67^{\star}$ & 54 \\
\hline \multicolumn{3}{|l|}{ В m.ч. } \\
\hline Постсоветские 3С & 55 & $46^{* * *}$ \\
\hline Местный с 1990 г. & $24^{*}$ & 5 \\
\hline Всего & $80^{* *}$ & 61 \\
\hline
\end{tabular}

* Доля может быть выше (68 \% для регионального и $29 \%$ для местного уровня), учитывая, что некоторые персоны после 1990 г. занимали руководящие посты в исполкомах и неясно, были ли они при этом депутатами.

** В этой и других таблицах цифра в итоговой строке может быть меньше суммы цифр в предыдущих строках, поскольку одна и та же персона может иметь опыт работы в различных органах.

*** Понятно, что все спикеры были депутатами перед избранием, но в тех случаях, когда, будучи избраны в 3С, они практически сразу стали спикерами, это депутатство не считалось их предшествующей должностью.

Наиболее широко распространено членство в легислатурах регионального уровня, к которым были отнесены не только ЗС, но и их предшественники - областные (краевые, республиканские, окружные) советы народных депутатов последнего (1990 г.) созыва. Причем некоторые будущие спикеры 3С были председателями этих советов (25 человек) или занимали в них другие руководящие посты, а после прекращения их полномочий и избрания 3С первого созыва в ряде случаев сразу возглавили эти органы. Однако гораздо чаще избранию спикером постсоветской региональной легислатуры предшествовала более или менее длительная законодательная карьера в ней. Многие будущие 
спикеры сначала занимали иные, менее высокие руководящие должности в парламенте, которые стали трамплином к посту председателя. Данные на этот счет неполны, но как минимум каждый пятый прежде был вице-спикером, примерно столько же возглавляли постоянные комитеты и комиссии, причем чаще всего ключевой комитет по бюджету (далее с большим отставанием следует комитет по законодательству). В целом те или иные руководящие должности в легислатурах (включая посты руководителей фракций и групп) занимали не менее трети будущих спикеров. Следует также отметить, что нередко до вхождения в должность они уже более или менее длительное время работали в легислатуре на постоянной, профессиональной, оплачиваемой основе (что во многих случаях предусмотрено нормативными актами в отношении таких постов, как председатели комитетов и вице-спикеры), посвящая законодательной деятельности все свое рабочее время, а не несколько часов в месяц, остающихся после выполнения иной, основной работы. У значительного меньшинства спикеров региональная легислатура была единственным местом работы прямо перед избранием, причем доля таких персон с 1990-х годов возросла (табл. 4).

Таблица 4

Доля спикеров, единственным местом работы которых перед избранием было 3С, по времени вхождения в должность, в \%

\begin{tabular}{|c|c|}
\hline Время вхождения в должность & Доля \\
\hline 1990 -е $(\mathrm{n}=160)$ & $9\left(19^{*}\right)$ \\
\hline 2000 -е $(\mathrm{n}=166)$ & 36 \\
\hline 2010 -е $(\mathrm{n}=135)$ & 34 \\
\hline
\end{tabular}

* Включая последний совет народных депутатов.

Предшествующая работа в легислатуре, особенно на руководящих постах, а также политическая профессионализация могут быть важны для спикеров, потому что позволяют им приобрести политические знания, умения и навыки необходимые для того, чтобы впоследствии возглавить законодательный орган. Они дают возможность завоевать доверие и авторитет, репутацию компетентного, эффективного парламентария среди коллег-депутатов, у которых в этом случае есть возможность более или менее длительное время наблюдать за работой будущих спикеров на законодательном поприще [Heinsohn, Schiefer 2019]. Получившая существенное распространение практика избрания 
спикеров, как и других руководителей легислатур, из числа относительно опытных депутатов-профессионалов с более или менее длительным стажем работы в них на менее высоких постах может рассматриваться как один из индикаторов и одновременно факторов определенной автономии законодательных органов от внешних сил и интересов, которая, в свою очередь, выступает показателем их институционализации (в этой связи см.: [Хантингтон 2004: 40]). Однако эту тенденцию не следует преувеличивать: легислатуры типично являются слабыми институтами, сильно зависимыми от администраций и бизнеса. В этом смысле показательно, что описанное «внутреннее» рекрутирование спикеров сосуществует с иной тенденцией. Вообще большинство спикеров, работавших в 3С до вхождения в должность, заседали там недолго: лишь каждый десятый - в двух и более созывах, не считая того, в котором был впервые избран спикером. Без малого у половины региональная легислатура (3С или последний совет) не была непосредственно предшествующим местом работы, а многие из тех, у кого была, совмещали депутатство с иной работой. Примерно в 20 \% случаев спикерами становились персоны, по-видимому, вообще не имевшие законодательного опыта после 1990 г. Среди таких спикеров особенно много прямых выходцев из региональной администрации. Тесная связь с влиятельными «внешними» интересами, контролирующими легислатуру (не только административными, но и экономическими), может служить мощным вытягивающим фактором законодательной карьеры, освобождая спикеров от необходимости предварительного политического «ученичества» в парламенте. Один из ярких примеров - нынешний председатель 3С Вологодской области А.Н. Луценко, который сделал карьеру в системообразующей для экономики региона компании «Северсталь», затем два года работал первым заместителем губернатора и с этого поста был избран депутатом и сразу же спикером легислатуры.

Как показывает приведенная выше таблица 3, членство в региональных легислатурах - не единственный тип предшествующего законодательного опыта, распространенного среди спикеров, которые перед занятием должности также входили в представительные органы другого более низкого или высокого уровня. В них они тоже могли в той или иной степени приобретать необходимые для успешной региональной законодательной карьеры политические навыки, известность и авторитет, связи в элитах и пр. Мы видим, что нередки случаи восходящей законодательной карьеры от местного к региональному уровню пред- 
ставительной власти. Вместе с тем встречаются и, напротив, примеры формально нисходящей законодательной карьеры, когда спикеры, перед тем как занять свой пост, работали в федеральных представительных органах, причем в СФ чаще, чем в ГД. Что касается СФ, то спикеры 3С чаще всего были депутатами его первого созыва, а затем совмещали членство в обоих органах. Хотя ситуация варьирует, представляется, что для рядового члена Федерального собрания пост спикера регионального законодательного органа может быть привлекательным и фактически представлять собой повышение, карьерный рост.

\section{Длительность пребывания в должности}

Говоря о законодательном опыте спикеров, нужно, конечно, затронуть вопрос и о длительности их пребывания на своем посту. Существует очень большой разброс в этом плане, однако чаще всего оно было недолгим. Так, более трети (35 \%) спикеров, которые уже покинули свою должность, не смогли сохранить свое кресло даже в течение одного полного созыва. Примерно столько же занимали свой пост один полный созыв. В то же время только 9 \% уже ушедших спикеров возглавляли легислатуры в течение трех и более созывов. Что касается ныне действующих спикеров, то более половины их заняли свою должность лишь в нынешнем созыве легислатуры, еще примерно 35 \% возглавляли также предыдущий созыв собрания. Однако среди спикеров есть и примеры удивительного политического долгожительства. Так, председатели легислатур Хакасии и Омской области возглавляют их с первого до нынешнего созыва. Сменяемость спикеров может быть связана с различными факторами, в числе которых, например, приход нового губернатора, стремящегося поставить во главе легислатуры своего человека, а также сдвиги в расстановке партийно-политических сил в парламенте (например, случаи перехода контроля над ним от КПРФ к ЕР в регионах бывшего «красного пояса»). Чтобы удержать свой пост при всех изменениях политической конъюнктуры, спикерам, по-видимому, нужно проявить немалое политическое мастерство. Следует также отметить, что типичная политическая слабость легислатур может нести ответственность за частую смену их спикеров в том смысле, что способна повышать для них привлекательность ключевых должностей в органах, где сосредоточена реальная власть, а именно в региональных администрациях, побуждая их искать и использовать возможности соответствующего перехода. 


\section{Законодательный опыт после ухода с должности}

Работа в представительных органах различного уровня - наиболее распространенный вариант карьеры спикеров после ухода со своего поста, характерный для большинства (табл. 5).

Таблииа 5

Членство спикеров в представительных органах после отставки, в \% $(\mathrm{N}=361)$

\begin{tabular}{|l|c|c|}
\hline \multicolumn{1}{|c|}{ Уровень легислатуры } & \multicolumn{1}{|c|}{$\begin{array}{c}\text { Наличие опыта } \\
\text { членства }\end{array}$} & $\begin{array}{c}\text { Первая известная } \\
\text { должность после } \\
\text { отставки }\end{array}$ \\
\hline Федеральное собрание & 29 & 21 \\
\hline В т.ч. & \multicolumn{2}{|c|}{} \\
\hline ГД & 10 & 6 \\
\hline СФ* & 20 & $16^{* *}$ \\
\hline Региональные 3С & 54 & 46 \\
\hline Местные думы & 2 & 64 \\
\hline Всего & 72 & 1 \\
\hline
\end{tabular}

* C учетом также тех, кто хотя бы некоторое время после ухода с поста спикера сохранял место в СФ, занятое по этой должности, но вновь в СФ не делегировался, доля экс-спикеров, заседавших в СФ, возрастет до $38 \%$, в ФС - до $45 \%$, в любых представительных органах — до 80 \%, причем сразу после отставки - до 36, 41 и 75 \% соответственно.

** В тех случаях, когда спикер после отставки избирался депутатом (или губернатором) и практически сразу входил в СФ, членство в СФ считалось также первой известной должностью.

Законодательную посткарьеру можно также формально разделить на два типа: нисходящую и восходящую. Нисходящая карьера имеет место тогда, когда спикер переходит на менее высокую руководящую позицию в региональной легислатуре (вице-спикер, председатель комитета и пр.) или становится рядовым депутатом, иногда совмещая этот пост с иной работой, а в отдельных случаях даже оказывается на местном уровне представительной власти. В некотором смысле региональное депутатство - самый простой и естественный вариант непосредственного продолжения карьеры после ухода с поста спикера. Так, если он покидает свою должность не с окончанием работы данного созыва легислатуры, а в течение созыва (что происходит нередко), он может автоматически сохранять депутатские полномочия, если, конечно, его 
уход не связан с переходом в органы, работа в которых несовместима с депутатством (например, в администрацию). Некоторые экс-спикеры просто досиживали свой срок в легислатуре и не баллотировались в ее очередной созыв. Однако чаще им удавалось избираться и в новые созывы легислатуры, пользуясь преимуществами инкумбентов. И все же не стоит преувеличивать вероятность этого варианта посткарьеры: некоторым спикерам, которые, находясь в должности, наживали себе немало врагов как среди избирателей, так и в элитах не удавалось пройти в новый созыв. Кроме того, после пребывания на высшей позиции в парламенте иные посты в нем могли быть для экс-спикеров просто непривлекательны, так что они воздерживались от продолжения региональной законодательной карьеры.

Формально восходящая карьера имела место, когда экс-спикер оказывался в ФС - ГД, а чаще в СФ. Что касается переходов в СФ, то они были особенно распространены в начале 2000-х годов, когда большая группа спикеров, входивших по должности в верхнюю палату, осталась в ней (обычно на довольно короткий срок) после изменения порядка ее формирования (опыт работы в этом органе и связи на федеральном уровне были их важными преимуществами в плане такого делегирования). Нужно отметить, что предоставление спикеру места в Федеральном собрании, может быть, кроме прочего, и способом относительно гладкой и бесконфликтной смены председателя и обеспечения его последующей лояльности. Переходы в ФС могут быть привлекательными для спикеров, учитывая щедрость вознаграждений парламентариев, их неприкосновенность, доступ к федеральным чиновникам, престижность парламентских постов и пр.

\section{РАБОТА СПИКЕРОВ В АДМИНИСТРАТИВНЫХ ОРГАНАХ ДО ВХОЖДЕНИЯ В ДОЛЖНОСТЬ И ПОСЛЕ ОТСТАВКИ}

\section{Предшествующий административный опыт}

Более половины спикеров имеют в своей предшествующей постсоветской карьере административный опыт, причем большинство чиновников, ставших председателями 3С, совершили прямой переход на этот пост (табл. 6). Примерно 30 \% провели в административных структурах не менее половины карьеры после 1991 г. и до того момента, как возглавили легислатуру. 
Таблица 6 Постсоветский опыт работы спикеров в административных органах до вхождения в должность, в \% $(\mathrm{N}=461)$

\begin{tabular}{|l|c|c|}
\hline Уровень администрации & $\begin{array}{c}\text { Наличие опыта } \\
\text { работы }\end{array}$ & $\begin{array}{c}\text { Последняя известная } \\
\text { должность перед избранием }\end{array}$ \\
\hline Федеральная夫 & 10 & 3 \\
\hline Региональная & 34 & 20 \\
\hline Местная & 26 & 10 \\
\hline Всего & 55 & 33 \\
\hline
\end{tabular}

* К федеральной администрации были, кроме прочего, отнесены территориальные органы федеральных органов исполнительной власти (в частности, органы внутренних дел в субъектах РФ), но надо учитывать, что они могут существенно зависеть от региональной исполнительной власти, глав регионов, что было характерно прежде всего для 1990-х годов.

Наиболее широко представлены выходцы из региональной исполнительной власти и, хотя существенно реже, местных администраций. Практика избрания спикерами как косвенных, так и прямых выходцев из администраций субъектов РФ широко распространена в региональном разрезе и встречается в подавляющем большинстве регионов. При этом в 16 субъектах РФ соответствующий опыт имели большинство спикеров (например, в Ингушетии - 9 из 10). В региональных администрациях будущие спикеры занимали прежде всего посты заместителей губернаторов (председателей правительств), реже - руководителей органов исполнительной власти (министров, председателей комитетов и пр.), советников или помощников губернаторов, при этом значительное число работало на высших должностях в администрации (аппарате) главы региона. Лишь в отдельных случаях спикерами становились бывшие губернаторы, чаще всего вынужденные по тем или иным причинам оставить свой пост, как, например, Э.Э. Россель, уволенный президентом за превышение полномочий, и А.Г. Тулеев, ушедший в отставку вскоре после пожара в ТЦ «Зимняя вишня». Что касается выходцев из местных администраций, то чаще всего будущие спикеры работали главами районов и городов, иногда их заместителями. Значительно меньше спикеров имеют предшествующий опыт работы в федеральной администрации, причем почти исключительно в руководстве территориальных подразделений в соответствующих субъектах РФ федеральных органов исполнительной власти (включая силовые ведом- 
ства, главным образом МВД, но также ФСБ, ФСНП и пр.) и администрации президента (прежде всего полномочные представители президента и главные федеральные инспекторы). При этом лишь в единичных случаях спикеры работали в центральном, базирующемся в Москве аппарате федеральных административных структур (двое, А.Г. Тулеев и А.Г. Назарчук, даже были федеральными министрами). Вообще надо отметить, что, в отличие от многих губернаторов, спикеры, за редким исключением, являются по характеру своей предшествующей карьеры эндогенными, укорененными в региональном (элитном) сообществе фигурами.

Что касается исторической динамики распространенности административного опыта, то здесь ситуация неоднозначна. В целом доля спикеров с предшествующим административным опытом в постсоветский период росла (табл. 7).

Таблица 7

Предшествующий постсоветский опыт работы спикеров в административных органах по времени вхождения в должность, в \%

\begin{tabular}{|c|c|c|c|c|}
\hline \multirow{2}{*}{$\begin{array}{c}\text { Уровень } \\
\text { администрации }\end{array}$} & \multirow[b]{2}{*}{ Показатель } & \multicolumn{3}{|c|}{ Время вхождения в должность } \\
\hline & & $\begin{array}{c}1990-e \\
(n=160)\end{array}$ & $\begin{array}{c}2000-e \\
(n=166)\end{array}$ & $\begin{array}{c}2010-e \\
(n=135)\end{array}$ \\
\hline \multirow[b]{2}{*}{ Федеральный } & наличие опыта & 6 & 8 & 15 \\
\hline & $\begin{array}{l}\text { последняя известная } \\
\text { должность перед } \\
\text { избранием }\end{array}$ & 3 & 4 & 2 \\
\hline \multirow[b]{2}{*}{ Региональная } & наличие опыта & 28 & 36 & 39 \\
\hline & $\begin{array}{l}\text { последняя известная } \\
\text { должность перед } \\
\text { избранием }\end{array}$ & 22 & 19 & 18 \\
\hline \multirow[b]{2}{*}{ Местная } & наличие опыта & 24 & 30 & 26 \\
\hline & $\begin{array}{l}\text { последняя известная } \\
\text { должность перед } \\
\text { избранием }\end{array}$ & 17,5 & 7 & 4 \\
\hline \multirow[b]{2}{*}{ Всего } & наличие опыта & 52 & 55 & 57 \\
\hline & $\begin{array}{l}\text { последняя известная } \\
\text { должность перед } \\
\text { избранием }\end{array}$ & 42,5 & 30 & 24 \\
\hline
\end{tabular}

Однако прежде всего увеличилась доля выходцев из региональной и федеральной администраций, в то время как доля местных чиновни- 
ков была относительно стабильна. При этом доля прямых выходцев из чиновничества существенно снизилась, прежде всего за счет руководителей местных администраций. Здесь надо отметить, что в 1990-е годы допускалось совмещение этих постов с депутатством, что во многом обусловило массовый приток местных чиновников в ЗС. Ряд таких персон сначала сочетали региональную законодательную карьеру с административной работой, а потом уже перешли с бюрократического поста на должность спикера.

Высокопоставленные чиновники обладают ресурсами и возможностями, повышающими их шансы на избрание как в легислатуру, так и на пост спикера. Властная позиция позволяет обеспечивать лояльность избирателей, например предоставляя им различные блага в рамках машинной политики. Широко распространено и влияние чиновников на выборы «через избирательное применение формальных норм и формирование специальных внелегальных практик, связанных, например, с контролем над деятельностью избирательных комиссий» [Барсукова, Левин 2020: 45-46]. Важно отметить, что ключевая административная должность дает возможность приобретать поддержку и со стороны различных элит. Прежде всего это губернатор, чаще всего оказывающий решающее влияние на выборы легислатуры и ее спикера. Стремясь обеспечить контроль над 3С, он может быть заинтересован в том, чтобы поставить во главе него людей из своей клиентелы, «команды», прежде всего коллег по администрации. Кроме того, значима и поддержка других властных акторов, которую они могут оказывать вследствие своей зависимости от администрации, прежде всего бизнеса и бюджетников, широко представленных в легислатурах. Наконец, в рекрутировании спикеров существенную, даже решающую роль, особенно в условиях централизации власти с 2000-х годов, могла играть и федеральная администрация, поддержка которой, возможно, была особенно важна для ряда глав легислатур - прямых выходцев из нее, в частности из аппарата полпредств Президента РФ (но примечательно, что их доля в этот период практически не возросла).

Говоря о заинтересованности чиновников в законодательной карьере, следует отметить, что, конечно, для высокопоставленных администраторов превращение в рядовых депутатов было бы явным понижением и утратой реальной власти, однако обычно они сразу занимают должности спикеров или других руководителей легислатур. Спикер, несмотря на типичную слабость 3С, обычно, если судить по рейтингам, 
одна из самых влиятельных фигур в региональной политической элите, так что переход на эту должность, к тому же высокооплачиваемую, может быть привлекательным даже для видных чиновников, будучи показателем восходящей карьеры. Впрочем, конечно, не всегда. И для некоторых, как, например, для экс-губернатора Кемеровской области А.Г. Тулеева, избрание спикером, очевидно, было закатом политической карьеры, почетной отставкой и пенсией [В Кремле назвали новое место работы... 2020].

\section{Административный опыт после ухода с должности}

Как показывает таблица 8, спикеры не только рекрутируются из чиновников разного уровня, но и работают в администрации после ухода с должности, тем не менее административный опыт сразу после отставки существенно менее распространен, чем непосредственно перед избранием главой легислатуры.

Таблица 8

\section{Работа спикеров в административных органах после ухода с должности, в \% $(\mathrm{N}=361)$}

\begin{tabular}{|l|c|c|}
\hline $\begin{array}{c}\text { Уровень } \\
\text { администрации }\end{array}$ & Наличие опыта работы & $\begin{array}{c}\text { Первая известная должность } \\
\text { после отставки }\end{array}$ \\
\hline Федеральная & 9 & 3 \\
\hline Региональная & 29 & 15 \\
\hline Местная & 4 & 2 \\
\hline Всего & 36 & 20 \\
\hline
\end{tabular}

В некоторых случаях бывшие спикеры возглавляли местные администрации, иногда работали в полномочных представительствах президента (прежде всего ГФИ и полпредами в регионах) и территориальных органах федеральных органов исполнительной власти (чаще всего их руководителями). В редких случаях они оказывались в центральном, «московском» административном аппарате, в том числе и на элитных должностях (трое - А.Г. Тулеев, Е.С. Сапиро, С.С. Собянин - стали членами правительства РФ). Впрочем, чаще всего бывшие главы легислатур работали в региональных администрациях на разных должностях, включая заместителей губернаторов (председателей правительств), советников (помощников) губернаторов, а также министров и других руководителей органов исполнительной власти субъектов РФ. Однако 
самой распространенной их региональной административной должностью был пост губернатора (35 случаев), причем обычно позиция спикера служила прямым трамплином к посту губернатора, чаще избранного населением и реже назначенного. Такая практика была довольно широко распространена в относительно демократических условиях 1990-х годов, тогда как в последующие десятилетия стала гораздо более редкой. Так, среди спикеров, покинувших свой пост в 1990-е годы, 18 \% сразу стали губернаторами (в этот период целому ряду спикеров, связанных с КПРФ и НПСР, удалось победить на выборах глав регионов), тогда как среди тех, кто ушел в 2000-е, только 2 \%, а в 2010-е - 5 \%.

Какие факторы могут влиять на распространенность административного опыта в посткарьере глав легислатур? Во-первых, то, что именно в административных структурах обычно сосредоточена реальная власть, может стимулировать интерес спикеров к переходу в них. Однако эта заинтересованность относится прежде всего к посту губернатора и применительно к более низким должностям ее не следует преувеличивать. Как бы ни слабы были часто законодательные органы, их председатели, возглавляя отдельную, особую ветвь региональной власти, формально считаются вторыми-третьими лицами субъектов РФ, которым не самые высокие посты в администрации могут казаться недостаточно престижными и привлекательными. Впрочем, при отсутствии других вариантов даже пост советника губернатора на общественных началах может быть в качестве формы почетной отставки с готовностью принят спикером, вынужденным по тем или иным причинам (возраст, скандал, проигрыш на выборах и пр.) покинуть свой пост. Губернатор, со своей стороны, может быть заинтересован в трудоустройстве спикера в администрацию, чтобы обеспечить его относительно бесконфликтный уход с должности и последующую лояльность.

Во-вторых, тот факт, что, как было показано выше, многие спикеры имеют предшествующий избранию опыт работы в административной сфере, а значит, и соответствующие знания, навыки и связи, может способствовать их административной карьере после ухода с должности. Существенная часть спикеров работала в администрации, как до вхождения в должность, так и после отставки. Впрочем, нельзя сказать, что среди спикеров, имевших административный опыт на любом из уровней власти после ухода с должности, соответствующий постсоветский опыт до вхождения в нее шире распространен, чем во всей совокупности. 
В-третьих, спикеры могут обладать и рядом других преимуществ, облегчающих достижение административных постов, прежде всего поста губернатора. Это и широкая известность в регионе, и опыт успешных избирательных кампаний, и видный пост в «партии власти», и связи с влиятельными персонами (чиновниками, бизнесменами), заседающими в легислатуре. Очень важно наличие у спикеров опыта и навыков урегулирования конфликтов, согласования интересов, создания коалиций внутри элиты, что может быть весьма полезно в работе на посту губернатора, чьей важнейшей задачей является выстраивание и поддержание собственной политической машины [Hale 2003: 248].

Впрочем, преимущества спикеров, релевантные достижению административных постов, не стоит преувеличивать. Представляется, что типичная слабость региональных легислатур как политических институтов, фактическое отсутствие подотчетности им региональных правительств в целом должны серьезно ограничивать способность их глав (как и депутатов в целом) претендовать на влиятельные административные посты, включая и должность главы региона. Кроме того, стоит отметить, что многие спикеры уходят со своего поста уже в пожилом возрасте (более четверти покинули его в 60 лет и старше). Это может существенно ограничивать (в силу проблем со здоровьем или возрастных ограничений на занятие должностей) их возможности продолжить карьеру в административной сфере (среди глав легислатур, покинувших должность в пенсионном возрасте, административный опыт встречался гораздо реже, чем во всей совокупности, причем в основном в качестве советников).

\section{БИЗНЕС КАК ИСТОЧНИК РЕКРУТИРОВАНИЯ СПИКЕРОВ И МЕСТО ИХ РАБОТЫ ПОСЛЕ ОТСТАВКИ}

\section{Предшествующий опыт работы в коммерческих организациях}

Как показывает таблица 9, свыше 40 \% спикеров имеют опыт работы на ключевых постах в коммерческих организациях после 1991 г. и до вхождения в должность.

Причем случаи рекрутирования на пост председателя 3С таких персон встречаются в подавляющем большинстве регионов, и во многих субъектах РФ (например, в Брянской, Иркутской, Ярославской областях, Приморском крае) соответствующий опыт работы имели большинство спикеров. Однако доля прямых выходцев из бизнеса, даже 
Таблица 9

Постсоветский опыт работы спикеров на ключевых должностях ${ }^{*}$ в коммерческих организациях до вхождения в должность, в \% $(\mathrm{N}=461)$

\begin{tabular}{|c|c|}
\hline Наличие опыта работы & $\begin{array}{c}\text { Последняя известная должность } \\
\text { перед избранием }\end{array}$ \\
\hline 42 & 14 \\
\hline
\end{tabular}

* К ним отнесены президенты, председатели советов директоров, председатели правлений и их заместители, директора по направлениям и индивидуальные предприниматели (не считая руководителей филиалов и представительств).

если учитывать не только ключевые, но и иные позиции (средний менеджмент, советники и пр.), гораздо меньше - около 17 \%, хотя случаи такого рекрутирования тоже имели место в большинстве регионов. О значимости опыта работы в коммерческих организациях говорит и то, что более четверти спикеров провели в них не менее половины своей постсоветской карьеры до вхождения в должность.

Если смотреть в исторической перспективе, то в сравнении с 1990-ми годами, наблюдается значительный рост доли спикеров с постсоветским опытом руководства бизнесом (табл. 10). Отчасти это неудивительно: чем больше времени прошло с 1991 г. до вступления спикера в должность, тем больше возможностей у него было поработать в постсоветских коммерческих структурах. Можно сказать, что в настоящее время работа на ключевых постах в бизнесе превратилась в типичную составную часть карьеры, ведущей к посту председателя региональной легислатуры.

Таблица 10

Предшествующий постсоветский опыт работы спикеров

на ключевых постах в коммерческих организациях по времени вхождения в должность, в \%

\begin{tabular}{|c|c|}
\hline Время вхождения в должность & Наличие опыта \\
\hline $1990-\mathrm{e}(\mathrm{n}=160)$ & 24 \\
\hline $2000-\mathrm{e}(\mathrm{n}=166)$ & 51 \\
\hline $2010-\mathrm{e}(\mathrm{n}=135)$ & 54 \\
\hline
\end{tabular}

Что касается роли бизнеса как непосредственного источника рекрутирования спикеров, то она изменилась не столь существенно: доля 
прямых выходцев с ключевых позиций в коммерческих организациях возросла, с 12,5 до 16 \% , а с любых позиций - с 14 до 20 \%.

Какой бизнес представлен среди спикеров? Касаясь формы собственности, можно отметить, что, хотя занятость в фирмах, которыми владеет государственная и муниципальная власть, включая унитарные предприятия, довольно распространена, все же существенно чаще встречается работа в частном секторе. Причем многие из тех спикеров, кто были заняты в бизнесе до избрания, сами владели им или принадлежали к семьям, владеющим компаниями. Есть и случаи непосредственного рекрутирования частных предпринимателей на этот пост. Один из примеров нынешний председатель Совета народных депутатов Кемеровской области В.А. Петров, являвшийся соучредителем и председателем совета директоров ООО «Е-Лайт-Телеком». В целом среди спикеров преобладают выходцы из компаний, принадлежащих местным собственникам (включая их самих), однако широко представлены и выходцы из фирм, контролируемых внешними, главным образом московскими, владельцами. В отраслевом плане примечательна распространенность занятости на предприятиях АПК, чьи которых руководители вообще часто играют важную роль в губернаторских политических машинах [Hale 2003]. Довольно широко представлен и опыт работы в финансовом, строительном секторах и торговле. В плане размера компаний нужно отметить, что среди спикеров с опытом работы в бизнесе значительная часть (в том числе большинство прямых выходцев из коммерческой сферы) работали в крупных по региональным меркам фирмах (которым нередко удавалось провести в 3С целую группу своих представителей). Это, в частности, характерно для регионов, в экономике которых есть предприятие-гегемон. Так, среди глав 3С Вологодской области большинство по роду свой работы были связаны с компанией «Северсталь», среди спикеров легислатуры Саха-Якутии двое работали на компании «Алроса», в Красноярском крае и на Таймыре спикерами становились прямые выходы с ГМК «Норильский никель». Также обращает на себя внимание тот факт, что в числе спикеров есть целый ряд прямых выходцев с предприятий-монополистов - энергетических и пр. Так, в 1990-е годы Магаданскую областную думу возглавлял В.А. Пехтин - руководитель компании «Колымаэнерго», а ЗС Иркутской области - генеральный директор компании «Иркутскэнерго» В.М. Боровский.

Значительная доля выходцев из бизнеса среди спикеров в общем неудивительна, учитывая их большой удельный вес во всем депутатском 
корпусе, откуда спикеры рекрутируются (см.: [Быстрова и др. 2019]). В условиях «кумовского капитализма», когда политические связи особенно важны для накопления капитала, бизнесмены могут быть заинтересованы в депутатском мандате (особенно в руководящем посте в легислатуре), поскольку он облегчает доступ к чиновникам [Szakonyi 2018] и позволяет прямо влиять на законотворчество. Притоку бизнеса в легислатуры способствует и институциональный дизайн этих органов, где большинство депутатов совмещают свои обязанности с основной работой [Кынев 2020: 684-686]. Важно также, что бизнесмены превосходят многие другие группы в плане ресурсов, которые можно мобилизовать на выборах депутатов легислатуры (а также отчасти ее спикера). Среди них деньги, корпоративные СМИ, структурная власть, подчиненные трудовые коллективы, репутация грамотных управленцев и пр. Причем экономический рост 2000-х годов способствовал увеличению политических ресурсов и возможностей бизнеса.

Однако, как показывают исследования, доля более или менее прямых выходцев из бизнеса в руководстве легислатур, включая спикеров, ниже, чем в депутатском корпусе в целом ([Быстрова и др. 2020]; см. также: [Reuter, Turovsky 2014]). Какие факторы могут ограничивать приток выходцев из бизнеса, особенно непосредственных, на пост спикера? Во-первых, должность спикера почти всегда предполагает работу в легислатуре на постоянной, оплачиваемой основе (хотя были исключения) и в этом смысле политическую профессионализацию. Более того, как уже отмечалось, карьерный путь к этой должности часто лежит через промежуточные между ней и рядовыми депутатами позиции, такие как председатели комитетов и вице-спикеры, работа на которых также нередко, согласно нормам законодательных органов, выполняется на профессиональной основе. Уже говорилось, что при прочих равных условиях персоне, которая совмещает депутатство с основной работой в бизнесе, уделяя ему, возможно, всего несколько часов в месяц, а не посвящает законодательной деятельности все свое рабочее время, труднее приобрести политические знания, умения и навыки, а также авторитет среди депутатов, необходимые для достижения руководящих должностей. При этом бизнесменам (особенно наемным менеджерам), в отличие от представителей многих иных социально-профессиональных групп, переход на постоянную, профессиональную работу в парламент может быть невыгоден в силу высоких издержек смены работы: покинув ключевой пост в компании, можно не только утратить контроль над ка- 
питалом, но и сильно проиграть в доходе. В этом смысле неудивительно, что в сравнении с обычными депутатами среди руководства легислатуры, включая спикеров, доля тех, кто непосредственно перед занятием должности работал в бизнесе, меньше и, как показало исследование, уступает доле тех председателей, у кого единственным местом работы была сама легислатура.

Во-вторых, как уже отмечалось, чаще всего легислатуры подконтрольны региональной исполнительной власти и губернаторы стремятся поставить на командные высоты в них, особенно на посты спикеров, людей из своей клиентелы, прежде всего выходцев из администрации. Частные бизнесмены могут казаться им слишком независимыми и недостаточно надежными для такой ответственной должности, хотя выходцы из прямо подконтрольных региональной власти государственных фирм могут больше подходить для этой роли. Впрочем, и зависимость частного бизнеса от региональных властей и его политическую лояльность губернатору также не стоит недооценивать.

В-третьих, бизнесмены могут считаться не лучшими кандидатами на пост спикера в силу того, что они имеют специфические коммерческие интересы и непосредственно вовлечены в соответствующие политико-экономические конфликты. Ведь одной из важнейших функций председателя легислатуры как раз является регулирование внутриэлитных конфликтов и согласование интересов (часто в основном деловых), представленных в ней (а также в региональной «партии власти», которую он нередко возглавляет). Для этого ему может быть необходима определенная автономия от указанных интересов. В этом смысле профессиональные политики и чиновники, если они существенно не вовлечены в бизнес (что, конечно, далеко не всегда так), могут считаться предпочтительными претендентами.

\section{Работа в бизнесе после отставки}

Как показывает таблица 11, спикеры имеют опыт работы в бизнесе не только до вхождения в должность, но, хотя и значительно реже, после отставки, занимая различные посты: топ-менеджеров, председателей и членов советов директоров, советников и пр.

При этом доля спикеров, ушедших в бизнес сразу после отставки, невелика, существенно меньше доли непосредственных выходцев оттуда. Лишь изредка должность главы легислатуры служила прямым трамплином к видным позициям в бизнесе, которым сами спикеры 
Таблииа 11

Работа спикеров в коммерческих организациях
после ухода с должности, в \% $(\mathrm{N}=361)$

\begin{tabular}{|l|c|c|}
\hline \multicolumn{1}{|c|}{ Должность } & Наличие опыта работы & $\begin{array}{c}\text { Первая известная должность } \\
\text { после отставки }\end{array}$ \\
\hline Ключевая & 18 & 4 \\
\hline Любая & 27 & 7 \\
\hline
\end{tabular}

не владели или в котором не работали до избрания. Например, главы парламентов Нижегородской области и Ненецкого автономного округа Е.Б. Люлин и В.А. Выучейский заняли посты в топ-менеджменте региональных дочек компании «Лукойл», а председатель Мосгордумы B.M. Платонов стал советником президента «Банка Москвы».

В каком бизнесе работали спикеры после отставки? Среди бывших председателей, имевших такой опыт, в том числе сразу после ухода с должности, шире распространена занятость в частных фирмах, чем в государственном и муниципальном секторе (например, в унитарных предприятиях и корпорациях развития). Причем значительная часть экс-председателей, работавших в частном бизнесе, владели им. Не менее трети отставных спикеров, занятых в коммерческой сфере, работали в крупном по региональным или даже федеральным меркам бизнесе. В частности, глава легислатуры Якутии В.Н. Басыгысов стал советником президента системообразующего для региональной экономики ПАО «Алроса», а председатель Законодательного собрания Вологодской области Г.Е. Шевцов получил пост советника генерального директора дочки ПАО «Северсталь» АО «Северсталь менеджмент». Около 2 \% экс-спикеров входили в топ-менеджмент или советы директоров компаний из списка журнала «Эксперт», т.е., по сути, в общероссийскую экономическую элиту. Однако прямых переходов в бизнес-элиту такого уровня было всего два. В частности, спикер Законодательного собрания Амурской области Н.Н. Швец занял пост генерального директора компании «Холдинг МРСК». Остальные бывшие спикеры обычно занимали перед переходом в крупный бизнес другие видные политикоадминистративные должности (такие как депутат ГД, заместитель федерального министра, губернатор), которые и становились прямым трамплином в экономическую элиту.

Какие факторы могут влиять на распространенность занятости спикеров в бизнесе после отставки? Во-первых, наличие у многих спи- 
керов предшествующего опыта руководящей работы в компаниях и соответствующих знаний и связей может облегчать их уход в бизнес после отставки. Среди спикеров, которые после отставки работали топ-менеджерами или председателями советов директоров компаний, соответствующий опыт до вхождения в должность гораздо более распространен, чем во всей совокупности. В значительном числе случаев спикеры после отставки возвращались в собственный бизнес, а также в другие фирмы, в которых были прежде заняты. Так, глава Законодательного собрания Приморского края ЕА. Овечкин, вынужденный подать в отставку из-за уголовного дела, возглавил совет директоров «Дальневосточной промышленно-строительной компании», председателем которого работал на момент своего избрания. А председатель Архангельского областного собрания депутатов В.С. Фортыгин, бывший перед избранием генеральным директором компании «Севералмаз», через некоторое время после отставки занял пост заместителя руководителя этого предприятия.

Во-вторых, как уже отмечалось, значительная часть спикеров покидает свой пост уже в пожилом возрасте, а в бизнесе нет таких жестких формальных возрастных ограничений на занятие должностей, как на государственной службе или в бюджетной сфере. Впрочем, преклонный возраст может быть фактическим препятствием и для полноценной управленческой карьеры в бизнесе, даже если и позволяет занимать синекуры членов советов директоров или советников.

В-третьих, трудоустройству в бизнесе могут способствовать также знакомства и связи, приобретенные спикерами в период пребывания в должности и в ходе их постоянного взаимодействия с бизнесменами, широко представленными в легислатуре. Выгодный пост в бизнесе может быть и своего рода вознаграждением за лояльность его интересам, которую спикер проявил, будучи на своем посту. В свою очередь, связи с чиновниками могут способствовать рекрутированию председателей на видные посты в государственных компаниях.

В-четвертых, если политиков могут привлекать высокие вознаграждения в бизнесе, то самим фирмам может быть выгоден наем бывших спикеров, имеющих связи в политико-административной элите и доступ к политикам и чиновникам (возможно, и на федеральном уровне, учитывая то, что многие председатели по должности были членами СФ), а также хорошо знающих механизм функционирования законодательной власти и законотворческий процесс. Наличие в компаниях таких 
персон может увеличивать лоббистские возможности бизнеса. Есть случаи, когда бывшие спикеры отвечали в фирмах именно за взаимодействие с органами государственной власти, как, например, В.В. Филиппов - председатель Государственного собрания Якутии, ставший советником ПАО «ФСК ЕЭС». Впрочем, заинтересованность фирм в привлечении спикеров не стоит переоценивать. Типичная слабость и зависимость региональных легислатур должны снижать лоббистский потенциал и востребованность в фирмах их председателей. Поскольку реальная власть обычно сосредоточена не в законодательных, а в административных органах, бизнес, вероятно, с гораздо большей готовностью возьмет на работу экс-чиновника, чем депутата, даже высокопоставленного. Кроме того, значительное различие логик функционирования политики и бизнеса и соответственно склонностей, способностей и навыков, необходимых для успешной работы в этих сферах, также ограничивает востребованность в фирмах политических деятелей, как и, вероятно, их собственный интерес к бизнес-карьере.

\section{ЗАКЛЮЧЕНИЕ}

Исследование карьеры спикеров региональных легислатур позволило сделать ряд выводов об основных каналах и тенденциях их рекрутирования, о доминирующих типах профессионального опыта как до избрания, так и после отставки, которые в биографиях конкретных властных персон нередко сочетаются.

Во-первых, для спикеров характерна высокая степень укорененности в органах политико-административной власти советского общества. Пути деятелей номенклатуры к посту председателя легислатуры различны: некоторые сначала заняли руководящие посты в последних советах народных депутатов, а затем возглавили 3С первого созыва, другие в постсоветский период сначала работали в административных или коммерческих структурах, которые и стали трамплином к спикерству. Впрочем, со временем доля номенклатурных, прежде всего партийных, кадров в спикерском корпусе значительно снизилась.

Во-вторых, самым распространенным среди спикеров типом профессионального опыта в постсоветский период как до избрания, так и после ухода с должности является законодательный опыт. Важным каналом их рекрутирования выступают сами региональные легислатуры, в которых будущие спикеры нередко случаев сначала занимали, 
в том числе на профессиональной основе, промежуточные руководящие позиции - вице-спикеров и председателей комитетов. Такое «внутреннее» рекрутирование спикеров может свидетельствовать об известной автономизации законодательных органов и в связи с этим их институционализации. Однако указанная тенденция довольно ограниченна: тесная связь с влиятельными внешними (административными, экономическими) интересами, контролирующими легислатуру, может служить мощным «вытягивающим» фактором законодательной карьеры, освобождая спикеров от необходимости предварительного политического «ученичества» в 3С.

В-третьих, один из важных каналов рекрутирования спикеров административные органы, прежде всего регионального и местного уровня, что во многом отражает (и, в свою очередь, закрепляет) зависимость формирования и функционирования легислатур от губернаторов, стремящихся поставить во главе них персон из своей клиентелы. Хотя исторически доля председателей с опытом работы в администрации довольно стабильна и даже немного возросла, прямых выходцев оттуда становится меньше. Работают спикеры в администрации и после отставки (хотя и реже), прежде всего на посту губернатора. Практика их прямого рекрутирования на должность главы региона была наиболее распространена в относительно демократические 1990-е годы, когда, в частности, ряду спикеров, связанных с КПРФ, удалось победить на выборах губернатора. Вообще приобретенные на посту спикера опыт и навыки урегулирования конфликтов, согласования интересов, создания коалиций внутри элиты могут быть довольно полезны для главы региона, чьей важнейшей задачей является выстраивание и поддержание собственной политической машины.

В-четвертых, значимым источником рекрутирования спикеров служит бизнес, причем его роль имеет тенденцию к росту. Широкое присутствие персон с опытом работы в бизнесе среди спикеров ожидаемо, учитывая высокий уровень плутократизации регионального депутатского корпуса в целом, связанный во многом с «кумовским» характером капитализма в России, когда политические связи первостепенны для накопления капитала. Однако непосредственных выходцев из бизнеса (чаще всего крупного по региональным меркам) относительно немного, что может отражать как важность предварительной политической профессионализации (не всегда выгодной бизнесменам) для достижения этого поста, так и зависимость легислатур от губернаторов, 
которым частные предприниматели могут казаться слишком самостоятельными фигурами для должности спикера. Значительно реже спикеры заняты в бизнесе после ухода с должности, причем довольно распространены случаи их возвращения в компании, в которых они работали до избрания на свой пост.

Наконец, если в общем говорить о роли поста спикера в карьере, то нужно отметить, что она различна. В частности, пост спикера мог быть как ее вершиной, так и, в некоторых случаях, закатом или же трамплином к более высоким позициям. В этой связи примечательно, что подавляющее большинство отставных спикеров занимали в дальнейшем элитные должности, хотя часто это были только менее значимые посты в самом 3С. Лишь меньшинство вовсе выпадало из элиты. Так, всего около четверти (нередко персоны пенсионного или предпенсионного возраста) не работали после ухода с должности на элитных политических или административных постах регионального или федерального уровня, даже если не учитывать «досиживаний» в СФ или текущем созыве 3С.

\section{Литература}

Барсукова С.Ю., Левин С.Н. Соотношение административного и финансового ресурсов в ходе избирательных кампаний в современной России: региональная специфика // Мониторинг общественного мнения: экономические и социальные перемены. 2020. № 4. С. 41-59.

Богатырева Л.В. Механизмы рекрутирования глав региональных законодательных собраний (на примере регионов ЦФО) // Политическая наука. 2012. № 1. C. 175-189.

Быстрова А.С. Типы карьер представителей региональной административно-политической элиты и факторы, влияющие на карьерные различия // Властные структуры и группы доминирования / под. ред. А.В. Дуки. СПб.: Интерсоцис, 2012. С. 76-93.

Быстрова А.С., Даугавет А.Б., Дука А.В., Колесник Н.В., Невский А.В., Тев Д.Б. Институционализация политической элиты: источники рекрутирования и карьера // Власть и элиты. 2019. Т. 6, № 2. С. 24-66.

Быстрова А.С., Даугавет А.Б., Дука А.В., Колесник Н.В., Невский А.В., Тев Д.Б. Региональная политическая элита: бассейн рекрутирования и карьера // Власть и элиты. 2020. Т. 7, № 1. С. 76-122.

Гельман В.Я. Региональная власть в современной России: институты, режимы и практики // Полис. Политические исследования. 1998. № 1. С. 87-105.

Даугавет А.Б. Представительная власть Санкт-Петербурга как неформальный институт (2000-2011) // Властные структуры и группы доминирования / под. ред. А.В. Дуки. СПб.: Интерсоцис, 2012. С. 344-369. 
Крыштановская O.B. Трансформация старой номенклатуры в новую российскую элиту // Общественные науки и современность. 1995. № 1. C. 51-65.

Кузьмин А.С., Мелвин Н.Дж., Нечаев В.Д. Региональные политические режимы в постсоветской России: опыт типологизации // Полис. Политические исследования. 2002. № 3. С. 142-155.

Кьнев A.B. Губернаторы в России: между выборами и назначениями. М.: Фонд «Либеральная миссия», 2020. 1030 с.

Петров Н. Корпоративизм vs регионализм // Pro et Contra. 2007. № 4-5 (38). С. 75-89.

Региональные элиты Северо-Запада России: политические и экономические ориентации / под ред. А.В. Дуки. СПб.: Алетейя, 2001. 352 с.

Сафронов B.B. Консолидация авторитаризма или демократизация: поддержка путинского режима элитой С.-Петербурга // Условия и возможности консолидации российского общества: сб. науч. трудов СИ РАН / отв. ред. А.В. Дука, И.И. Елисеева. СПб.: Нестор-История, 2010. С. 30-110.

Тев Д.Б. Депутаты Государственной Думы РФ VI созыва: социально-профессиональные источники рекрутирования // Экономическая социология. 2017. T. 18 , № 5. С. 52-86.

Тев Д.Б. Спикеры легислатур субъектов РФ: каналы рекрутирования и карьера // Социологический журнал. 2021. Т. 27, № 1. С. 52-75.

Туровский Р.Ф. Институциональный дизайн российской региональной власти: кажущаяся простота? // Общественные науки и современность. 2011. № 5. С. 82-92.

Туровский Р.Ф., Сухова М.С. Кооптация оппозиции в региональных парламентах России: игра с нарушением правил // Полития. 2021. № 2 (101). С. 121143.

Хантингтон С. Политический порядок в меняющихся обществах. М.: Прогресс-Традиция, 2004. 480 с.

Шириков А. Анатомия бездействия: Политические институты и конфликты в бюджетном процессе регионов России. СПб.: Изд-во Европейского университета в Санкт-Петербурге, 2010. 276 с. (Труды факультета политических наук и социологии).

Böröcz J., Róna-Tas Á. Small Leap Forward: Emergence of New Economic Elites // Theory and Society. 1995. Vol. 24, № 5 (Special Issue on Circulation vs Reproduction of Elites During the Postcommunist Transformation of Eastern Europe). P. 751-781.

Carnes $N$. Does the Numerical Underrepresentation of the Working Class in Congress Matter? // Legislative Studies Quarterly. 2012. Vol. 37, № 1. P. 5-34.

Carnes N., Lupu N. Rethinking the Comparative Perspective on Class and Representation: Evidence from Latin America // American Journal of Political Science. 2015. Vol. 59, № 1. P. 1-18. 
Chaisty P. The Preponderance and Effects of Sectoral Ties in the State Duma // Europe-Asia Studies. 2013. Vol. 65, № 4. P. 717-736.

Gandhi J., Przeworski A. Authoritarian Institutions and the Survival of Autocrats // Comparative Political Studies. 2007. Vol. 40, № 11. P. 1279-1301/

Golosov G. Growing Old Without Grace: Electoral Authoritarianism And The Age Composition Of Russia’s Regional Legislative Assemblies // Representation. 2014. Vol. 50, №4. P.509-526.

Golosov G.V. Legislative Turnover and Executive Control in Russia’s Regions (2003-2014) // Europe-Asia Studies. 2017. Vol. 69, № 4. P. 553-570.

Hale H.E. Explaining Machine Politics in Russia's Regions: Economy, Ethnicity, and Legacy // Post-Soviet Affairs. 2003. Vol. 19, № 3. P. 228-263.

Hanley E., Yershova N., Anderson R. Russia - Old Wine in a New Bottle? The Circulation and Reproduction of Russian Elites, 1983-1993 // Theory and Society. 1995. Vol. 24, № 5 (Special Issue on Circulation vs Reproduction of Elites During the Postcommunist Transformation of Eastern Europe). P. 639-668.

Heinsohn T., Schiefer M. Advancing to positions of power in parliament - does seniority matter? // The Journal of Legislative Studies. 2019. Vol. 25, № 4. P. 511-532.

Jensen N.M., Malesky E., Weymouth S. Unbundling the Relationship between Authoritarian Legislatures and Political Risk // British Journal of Political Science. 2014. Vol. 44, № 3. P. 655-684.

Malesky E., Schuler P. Nodding or Needling: Analyzing Delegate Responsiveness in an Authoritarian Parliament // American Political Science Review. 2010. Vol. 104, № 3. P. 482-502.

Reuter O.J., Robertson G.B. Legislatures, Cooptation, and Social Protest in Contemporary Authoritarian Regimes // The Journal of Politics. 2015. Vol. 77, № 1. P. 235-248.

Reuter O.J., Turovsky R. Dominant party rule and legislative leadership in authoritarian regimes // Party Politics. 2014. Vol. 20, № 5. P. 663-674.

Samuels D. Ambition, Federalism, and Legislative Politics in Brazil. Cambridge: Cambridge University Press, 2003.

Szakonyi D. Businesspeople in Elected Office: Identifying Private Benefits from Firm-Level Returns // American Political Science Review. 2018. Vol. 112, № 2. P. 322-338.

Szelényi I., Szelényi S. Circulation or Reproduction of Elites during the PostCommunist Transformation of Eastern Europe // Theory and Society. 1995. Vol. 24, № 5 (Special Issue on Circulation vs Reproduction of Elites During the Postcommunist Transformation of Eastern Europe). P. 615-638.

Witko C., Friedman S. Business Backgrounds and Congressional Behavior // Congress \& the Presidency. 2008. Vol. 35, № 1. P. 71-86.

Wright J. Do Authoritarian Institutions Constrain? How Legislatures Impact Economic Growth and Foreign Aid Effectiveness // American Journal of Political Science. 2008. Vol. 52, № 2. P. 322-342. 


\title{
Источники
}

В Кремле назвали новое место работы Тулеева «почетной ссылкой» // РБК. 11.04.2018. URL: https://www.rbc.ru/politics/11/04/2018/5accf5eb9a79471718b655 0d (дата обращения 12.05.2020).

\section{SPEAKERS OF REGIONAL LEGISLATURES: CAREER ROUTES AND RECRUITMENT CHANNELS}

\section{Tev}

(denis_tev@mail.ru) Sociological Institute of the Russian Academy of Sciences - a branch of the Federal Center of Theoretical and Applied Sociology of the Russian Academy of Sciences, St.-Petersburg, Russia

Citation: Tev D. Spikery regional'nykh zakonodatel'nykh sobraniy: kar'yernyye puti i kanaly rekrutirovaniya [Speakers of regional legislatures: career routes and recruitment channels]. Vlast' i elity [Power and Elites], 2021, 8 (1): 26-65. (in Russian)

DOI: https://doi.org/10.31119/pe.2021.8.1.2

\begin{abstract}
The article examines the channels for recruitment the speakers of the legislatures of the subjects of the Russian Federation and the features of their career, both before election and after leaving office. The empirical basis of the study is the biographical database of the chairmen of regional legislative assemblies of all convocations after the end of the term of the last councils of people's deputies and until February 2019. It has been established that the speakers are strongly rooted in the bodies of political-administrative power of Soviet society, although the share of the nomenklatura, first of all, party cadres have a pronounced tendency to decrease. The main channel for recruitment of speakers and their place of work after resignation are the representative authorities, primarily regional legislatures. The election of speakers from among relatively experienced professional deputies may indicate a certain autonomization and institutionalization of legislative assemblies. However, this tendency is rather limited: close ties with influential external forces (administrative, economic) that control the legislature can act as a "pulling" factor in legislative careers, freeing speakers from the need for preliminary political "apprenticeship" in parliament. Administrative bodies, primarily regional and local, are an important channel for recruitment of speakers, which, in many respects, reflects the dependence of the formation and functioning of legislatures on governors, who strive to put people from their clientele at the
\end{abstract}


head of them. Speakers are much less likely to work in administrative structures after their resignation, primarily as governor, and the practice of recruiting them for this position was most widespread in the 1990s. Business is a significant source of recruitment of speakers, however, there are relatively few direct descendants from commercial organizations (most often from large by regional standards), which may reflect both the importance of preliminary political professionalization to achieve this post, and control over legislative assemblies by governors, for whom private businessmen may seem too independent to be a speaker. Less often, speakers are engaged in business after leaving office, including their return to the companies in which they worked before the election.

Keywords: speakers, regional legislatures, recruitment channels, career, nomenclature experience, representative bodies, administrative bodies, business.

\section{References}

Barsukova S.Ju., Levin S.N. Sootnoshenie administrativnogo i finansovogo resursov v hode izbiratel'nyh kampanij v sovremennoj Rossii: regional'naja specifika [Ratio Between Administrative and Financial Resources during Election Campaigns in Modern Russia: Regional Specifics]. Monitoring obshhestvennogo mnenija: jekonomicheskie i social'nye peremeny [Monitoring of Public Opinion: Economic and Social Changes], 2020, 4, pp. 41-59. (In Russian)

Bogatyreva L.V. Mehanizmy rekrutirovanija glav regional'nyh zakonodatel'nyh sobranij (na primere regionov CFO) [Mechanisms for recruiting the heads of regional legislative assemblies (on the example of the regions of the Central Federal District)]. Politicheskaja nauka [Political Science], 2012, 1, pp. 175-189. (In Russian)

Böröcz J., Róna-Tas Á. Small Leap Forward: Emergence of New Economic Elites. Theory and Society, 1995, 24 (5) (Special Issue on Circulation vs Reproduction of Elites During the Postcommunist Transformation of Eastern Europe), pp. 751-781.

Bystrova A.S. Tipy kar'er predstavitelej regional'noj administrativno-politicheskoj jelity i faktory, vlijajushhie na karernye razlichija [Types of careers of representatives of the regional administrative-political elite and factors affecting career differences]. In: Vlastnye struktury i gruppy dominirovanija [Power structures and dominance groups.] Ed. by A.V. Duka. St. Petersburg: Intersocis, 2012, pp. 76-93. (In Russian)

Bystrova A.S., Daugavet A.B., Duka A.V., Kolesnik N.V., Nevskij A.V., Tev D.B. Institucionalizacija politicheskoj jelity: istochniki rekrutirovanija i kar'era [Institutionalization of the political elite: sources of recruitment and careers]. Vlast' $i$ jelity [Power and Elites]. 2019. Vol. 6. № 2. P. 24-66. (In Russian)

Bystrova A.S., Daugavet A.B., Duka A.V., Kolesnik N.V., Nevskij A.V., Tev D.B. Regional'naja politicheskaja jelita: bassejn rekrutirovanija i kar'era [Regional political elite: pool of recruitment and career]. Vlast' i jelity [Power and Elites]. 2020, 7 (1), pp. 76-122. (In Russian)

Carnes N. Does the Numerical Underrepresentation of the Working Class in Congress Matter? Legislative Studies Quarterly, 2012, 37 (1), pp. 5-34. 
Carnes N., Lupu N. Rethinking the Comparative Perspective on Class and Representation: Evidence from Latin America. American Journal of Political Science, 2015, 59 (1), pp. 1-18.

Chaisty P. The Preponderance and Effects of Sectoral Ties in the State Duma. Europe-Asia Studies, 2013, 65 (4), pp. 717-736.

Daugavet A.B. Predstavitel'naja vlast' Sankt-Peterburga kak neformal'nyj institut (2000-2011) [Representative power of St. Petersburg as an informal institution (2000-2011)]. In: Vlastnye struktury i gruppy dominirovanija [Power structures and dominance groups.] Ed. by A.V. Duka. St. Petersburg: Intersocis, 2012, pp. 344-369 (In Russian).

Gandhi J., Przeworski A. Authoritarian Institutions and the Survival of Autocrats. Comparative Political Studies, 2007, 40 (11), pp. 1279-1301.

Gel'man V.Ja. [Regional'naja vlast'v sovremennoj Rossii: instituty, rezhimy i praktikic] Regional Power in Modern Russia: Institutions, Regimes and Practices. Polis. Politicheskie issledovanija [Polis. Political Studies], 1998, 1, pp. 87-105. (In Russian)

Golosov G. Growing Old Without Grace: Electoral Authoritarianism And The Age Composition Of Russia's Regional Legislative Assemblies. Representation, 2014, 50 (4), pp. 509-526.

Golosov G.V. Legislative Turnover and Executive Control in Russia's Regions (2003-2014). Europe-Asia Studies, 2017, 69 (4), pp. 553-570.

Hale H.E. Explaining Machine Politics in Russia's Regions: Economy, Ethnicity, and Legacy. Post-Soviet Affairs, 2003, 19 (3), pp. 228-263.

Hanley E., Yershova N., Anderson R. Russia - Old Wine in a New Bottle? The Circulation and Reproduction of Russian Elites, 1983-1993. Theory and Society, 1995, 24 (5) (Special Issue on Circulation vs Reproduction of Elites During the Postcommunist Transformation of Eastern Europe), pp. 639-668.

Heinsohn T., Schiefer M. Advancing to positions of power in parliament - does seniority matter? The Journal of Legislative Studies, 2019, 25 (4), pp. 511-532.

Huntington S. Politicheskij porjadok $v$ menjajushhihsja obshhestvah [Political order in changing societies]. Moscow: Progress-Tradicija,2004. 480 p. (In Russian)

Jensen N.M., Malesky E., Weymouth S. Unbundling the Relationship between Authoritarian Legislatures and Political Risk. British Journal of Political Science, 2014, 44 (3), pp. 655-684.

Kryshtanovskaja O.V. Transformacija staroj nomenklatury v novuju rossijskuju jelitu [Transformation of the old nomenclature into a new Russian elite]. Obshhestvennye nauki i sovremennost' [Social Sciences and Contemporary World]. 1995, 1, pp. 51-65. (In Russian)

Kuz'min A.S., Melvin N.Dzh., Nechaev V.D. Regional'nye politicheskie rezhimy v postsovetskoj Rossii: opyt tipologizacii [Regional political regimes in post-Soviet Russia: the experience of typology]. Polis. Politicheskie issledovanija [Polis. Political Studies], 2002, 3, pp. 142-155. (In Russian) 
Kynev A.V. Gubernatory v Rossii: mezhdu vyborami i naznachenijami [Governors in Russia: Between Elections and Appointments]. Moscow: Fond «Liberal'naja missija», 2020. 1030 p. (In Russian)

Malesky E., Schuler P. Nodding or Needling: Analyzing Delegate Responsiveness in an Authoritarian Parliament. American Political Science Review, 2010, 104 (3), pp. 482-502.

Petrov N. Korporativizm vs regionalizm [Corporatism vs regionalism]. Pro et Contra, 2007, 4-5 (38), pp. 75-89. (In Russian)

Regional'nye jelity Severo-Zapada Rossii: politicheskie i jekonomicheskie orientacii [Regional elites of Russia's North-West: political and economic orientations]. Ed. by A.V. Duka. St. Petersburg: Aletejja, 2001. 352 p. (In Russian)

Reuter O.J., Robertson G.B. Legislatures, Cooptation, and Social Protest in Contemporary Authoritarian Regimes. The Journal of Politics, 2015, 77 (1), pp. 235-248.

Reuter O.J., Turovsky R. Dominant party rule and legislative leadership in authoritarian regimes. Party Politics, 2014, 20 (5), pp. 663-674.

Safronov V.V. Konsolidacija avtoritarizma ili demokratizacija: podderzhka putinskogo rezhima jelitoj S.-Peterburga [Consolidation of authoritarianism or democratization: support of the Putin regime by the elite of St. Petersburg]. In: Uslovija i vozmozhnosti konsolidacii rossijskogo obshhestva: Sbornik nauchnyh trudov SI RAN [Conditions and Opportunities for Consolidating Russian Society: Collection of Scientific Papers of the SI RAS.] Ed. by A.V. Duka, I.I. Eliseeva. St. Petersburg: NestorIstorija, 2010, pp. 30-110. (In Russian)

Samuels D. Ambition, Federalism, and Legislative Politics in Brazil. Cambridge: Cambridge University Press, 2003.

Shirikov A. Anatomija bezdejstvija: Politicheskie instituty i konflikty v bjudzhetnom processe regionov Rossii [Anatomy of Inaction: Political Institutions and Conflicts in the Budgeting Process of Russian Regions]. St. Petersburg: Izdatel'stvo Evropejskogo universiteta v Sankt-Peterburge, Serija: Trudy fakul'teta politicheskih nauk i sociologii, 2010. 276 p. (In Russian)

Szakonyi D. Businesspeople in Elected Office: Identifying Private Benefits from Firm-Level Returns. American Political Science Review, 2018, 112 (2), pp. 322-338.

Szelényi I., Szelényi S. Circulation or Reproduction of Elites during the PostCommunist Transformation of Eastern Europe. Theory and Society, 1995, 24 (5) (Special Issue on Circulation vs Reproduction of Elites During the Postcommunist Transformation of Eastern Europe), pp. 615-638.

Tev D.B. Deputaty Gosudarstvennoj Dumy RF VI sozyva: social'no-professional'nye istochniki rekrutirovanija [Deputies of the State Duma of the VI Convocation: Social-Professional Sources of Recruitment]. Jekonomicheskaja sociologija [Economic Sociology], 2017, 18 (5), pp. 52-86. (In Russian)

Tev D.B. Spikery legislatur sub\#\#ektov RF: kanaly rekrutirovanija i kar"era [Speakers of Legislatures of Subjects of the Russian Federation: Recruitment Channels 
and Career. Sociologicheskij zhurnal [Sociological Journal], 2021, 27 (1), pp. 52-75 (In Russian)

Turovskij R.F. Institucional'nyj dizajn rossijskoj regional'noj vlasti: kazhushhajasja prostota? [Institutional Design of Russian Regional Power: Seeming Simplicity?]. Obshhestvennye nauki i sovremennost' [Social Sciences and Contemporary World], 2011, 5, pp. 82-92. (In Russian)

Turovskij R.F., Suhova M.S. Kooptacija oppozicii v regional'nyh parlamentah Rossii: igra s narusheniem pravil [Co-optation of Opposition in Russian Regional Parliaments: Game that Breaks Rules]. Politija [Politeja]. 2021, 2 (101), pp. 121-143. (In Russian)

Witko C., Friedman S. Business Backgrounds and Congressional Behavior. Congress \& the Presidency, 2008, 35 (1), pp. 71-86.

Wright J. Do Authoritarian Institutions Constrain? How Legislatures Impact Economic Growth and Foreign Aid Effectiveness. American Journal of Political Science, 2008, 52 (2), pp. 322-342. 